\title{
1 Postglacial fluctuations of Cordillera Darwin glaciers (southernmost Patagonia) reconstructed \\ 2 from Almirantazgo fjord sediments
}

4 Sebastien Bertrand ${ }^{1,2,{ }^{*}}$, Carina B. Lange ${ }^{3,4}$, Silvio Pantoja ${ }^{3}$, Konrad Hughen ${ }^{2}$, Evi Van Tornhout ${ }^{1}$, Julia

5 Smith Wellner ${ }^{5}$

$6 \quad{ }^{1}$ Renard Centre of Marine Geology, Ghent University, Gent, Belgium

$7 \quad{ }^{2}$ Marine Chemistry and Geochemistry, Woods Hole Oceanographic Institution, MA, USA

$8{ }^{3}$ Department of Oceanography and COPAS Sur-Austral Center, Universidad de Concepción, Concepción, 9 Chile

${ }^{4}$ FONDAP-IDEAL Center, Universidad Austral de Chile, Valdivia, Chile

${ }^{5}$ Department of Earth and Atmospheric Sciences, University of Houston, TX, USA

*Corresponding author: sebastien.bertrand@ugent.be

\section{Abstract}

Most outlet glaciers of the Cordillera Darwin Icefield (CDI; Patagonia, $54^{\circ} \mathrm{S}$ ) are currently transitioning from calving to land-based conditions. Whether this situation is unique to the modern climate or also occurred during the Holocene is entirely unknown. Here, we investigate the Holocene fluctuations of outlet glaciers from the northern flank of the CDI using a multi-proxy sedimentological and geochemical analysis of a $13.5 \mathrm{~m}$ long sediment core from Almirantazgo fjord. Our results demonstrate that sedimentation in Almirantazgo fjord started prior to 14,300 cal yr BP, with glacier-proximal deposits occurring until 13,500 cal yr BP. After 12,300 cal yr BP, most glaciers had retreated to land-locked locations and by 9800 cal yr BP, Almirantazgo fjord was a predominantly marine fjord environment with oceanographic conditions resembling the present-day setting. Our sediment record shows that during the first part of the Holocene, CDI glaciers were almost entirely land-based, with a possible re-advance at 7300-5700 cal yr BP. This is in clear contrast with the Neoglaciation, during which CDI glaciers rapidly re-advanced and shrank back several times, mostly in phase with the outlet glaciers of the Southern Patagonian Icefield (SPI). Two significant meltwater events, indicative of rapid glacier retreat, were identified at 3250-2700 and 2000-1200 cal yr BP, based on an increase in grain-size mode and related inorganic geochemical parameters. This interpretation is additionally supported by concomitant decreases in organic carbon of marine origin and in $\mathrm{Cl}$ counts (salinity), reflecting higher terrestrial input to the fjord and freshening of the fjord waters. Overall, our record suggests that CDI outlet glaciers advanced in phase with SPI glaciers during the Neoglaciation, and retreated far enough into their valleys twice to form large outwash plains. Our results also highlight the potential of fjord sediments to reconstruct glacier variability at high resolution on multi-millennial timescales. 


\section{Keywords}

37 Fjord sediments, Ice-rafted debris, meltwater, Neoglaciation, Holocene

38

\section{Highlights}

40 Almirantazgo fjord sediments record CDI glacier variability during the last 14,300 years

41 CDI glaciers were relatively stable during the early- and mid-Holocene

42 They advanced and shrank back rapidly during the Neoglaciation

43 CDI glacier variability during the Neoglaciation occurred mostly in phase with the SPI 


\section{Introduction}

Patagonian glaciers are among the fastest retreating ice masses on Earth (Lemke et al., 2007). The reasons behind this exceptional retreat during the last few decades are frequently debated in the literature but they generally include a complex combination of increasing atmospheric temperature, decreasing precipitation, and accelerated calving (Rignot et al., 2003; Glasser et al., 2011), locally enhanced by wind-driven intrusions of warm ocean waters (Moffat, 2014). To better understand Patagonian glacier-climate relationships on longer, i.e., centennial, timescales, it is necessary to develop continuous records of glacier mass balance that extend beyond instrumental timescales. Several such glacier variability reconstructions were recently produced for the Northern (NPI) and Southern (SPI) Patagonian Icefields (e.g., Glasser et al., 2004; Bertrand et al., 2012a; Strelin et al., 2014). Comparatively, very few records exist for the glaciers of the southernmost Cordillera Darwin Icefield (CDI; Kuylenstierna et al., 1996, Strelin et al., 2008). The reason for this lack of southernmost records is largely related to the morphodynamic setting of most CDI glaciers, i.e., they are fjord-terminating, which results in very limited terrestrial evidence of glacier variability.

The existence of glaciers reaching sea level in Patagonia is mostly due to the very high precipitation that characterizes the area, which reflects the interruption of the westerly flow of humid air by the southern Andes (Garreaud et al., 2013). Given the mostly W-E orientation of Cordillera Darwin compared to the pure N-S orientation of the NPI and SPI (Fig. 1), CDI glaciers may respond very differently to changes in westerly wind-driven precipitation and results obtained on NPI and SPI glaciers cannot simply be extrapolated to CDI glaciers. Yet, CDI glaciers are the least studied of all Patagonian glaciers (Lopez et al., 2010). Reconstructing the fluctuations of CDI glaciers during the Holocene is therefore critically needed to obtain a more comprehensive understanding of the relation between climate and glacier variability in Patagonia.

Techniques traditionally used to reconstruct glacier variability, i.e., geomorphic mapping and exposure dating, are of relatively little use in Cordillera Darwin since most CDI glaciers are calving into fjords. This morphodynamic characteristic however offers the possibility to use the sediments from the fjords in which these glaciers calve to reconstruct glacier fluctuations (e.g., Howe et al., 2010; Andresen et al., 2011; Bertrand et al., 2012a). Compared to the traditional geomorphic and exposure dating approach, which provides notoriously discontinuous records of maximum glaciers advances, fjord sediments offer the advantage of holding continuous records of both glacier advance and retreat. They are particularly useful to detect calving/land-based transitions, based on the concentrations of ice-rafted debris (IRD), for example (Andresen et al., 2011; Kuijpers et al., 2014).

Although fjord sediments contain a huge potential for glacier mass balance reconstructions in the southern Andes, the number of records from the Patagonian fjords remains very limited (e.g., Boyd et al., 2008; Bertrand et al., 2012a). In addition, most of the existing work on proglacial fjord sediments in Chilean Patagonia focuses on the deglaciation (Boyd et al., 2008) and/or on quantifying erosion rates (Koppes et al., 2009, 2015; Fernandez et al., 2011). Very little attention has been paid to glacier variations recorded in Holocene fjord sediments. 
Here, we use a sediment core from Almirantazgo fjord $\left(54^{\circ} \mathrm{S}\right)$ to reconstruct the fluctuations of outlet glaciers from the northern flank of the CDI during the Holocene. Although our sediment core has previously been studied by Boyd et al. (2008), these authors focused on the deglaciation and they concluded that "during the Holocene, stable ice conditions persisted until the mid-1960s". In contrast, we use a detailed multi-proxy sedimentological and geochemical approach to provide evidence that CDI glaciers shrank and re-advanced several times during the Holocene, mostly in phase with SPI glaciers.

\section{Setting}

Cordillera Darwin holds the third largest temperate icefield in the Southern Hemisphere. It is located at $54.4-55^{\circ} \mathrm{S}$ (Fig. 1) and it is composed of 627 glaciers that cover a total area of $2333 \mathrm{~km}^{2}$ (Bown et al., 2014). The ice fronts of most CDI outlet glaciers reach sea level and a large fraction of CDI glaciers are currently transitioning from calving to land-based conditions (Porter and Santana 2003). The icefield is currently losing about $4.3 \mathrm{~km}^{3}$ of ice/year, mostly due to the rapid thinning of glaciers on the northern side (Melkonian et al., 2013). Since the Little Ice Age (LIA), it has lost a total area of $306 \mathrm{~km}^{2}$ (Davies and Glasser, 2012). Despite recent retreat throughout the area, nearly half of the CDI glaciers were either stationary or slightly advancing during the last decades (Holmund and Fuenzalida, 1995; Lopez et al., 2010; Davies and Glasser, 2012; Bown et al., 2014), reflecting the dynamic responses of different glaciers in the region.

The largest and most documented glacier of the CDI by far is Marinelli (Fig. 1), which has a total area of $133 \mathrm{~km}^{2}$ and a length of $21 \mathrm{~km}$ (Bown et al., 2014). Between 1913 and 2011, Marinelli glacier experienced a frontal retreat of $15 \mathrm{~km}$, most of which occurred after 1945 (Porter and Santana, 2003; Koppes et al., 2009; Bown et al., 2014). Between 1913 and 1945, the relatively stable ice front terminated near the arcuate moraine visible in satellite images (Fig. 1; Porter and Santana 2003). The atypical rapid retreat of Marinelli glacier during the last decades is mostly due to the geometry of the fjord sub-basins, which resulted in a slow retreat when the glacier was grounded until 1967 , and was followed by a rapid retreat once the glacier became detached from its pinning point (Fig. 1; Koppes et al., 2009).

Cordillera Darwin is located in the present-day core of the southern westerlies (Garreaud et al., 2013). It receives uniform precipitation throughout the year (Sagredo and Lowell 2012), which can reach up to $5000 \mathrm{~mm} / \mathrm{yr}$ on top of the icefield (PRECIS-DGF model from Garreaud et al., 2013; RACMO2 model from Lenaerts et al., 2014). The mean annual temperature at sea level reaches $5^{\circ} \mathrm{C}$, with extremes of $8^{\circ} \mathrm{C}$ in summer (Feb-Mar) and $1.8^{\circ} \mathrm{C}$ in winter (Aug; PRECIS-DGF model). According to Holmlund and Fuenzalida (1995) and Lopez et al. (2010), the E-W orientation of the CDI leads to an orographic effect with greater precipitation on southern and western glaciers and drier and warmer conditions around northern and eastern glaciers. This difference is however not clearly resolved by the most recent high-resolution climate models (Lenaerts et al., 2014).

Most of the northeastern CDI glaciers discharge into Almirantazgo fjord, generally via smaller intermediate fjords, such as Brookes fjord, Ainsworth Bay, and Parry fjord, from North to South (Fig. 1). Almirantazgo fjord therefore receives meltwater from several glaciers, including Gallegos, Marinelli, and 
the many small glaciers that reach Parry fjord (Fig. 1). As a result, the surface waters of Almirantazgo fjord are slightly brackish (<30 PSU) and flow towards the Northwest (Valdenegro and Silva 2003). The fjord bathymetry reaches $300 \mathrm{~m}$ in front of Ainsworth Bay, and it deepens towards the Northwest to reach values $>500 \mathrm{~m}$ at $54^{\circ} \mathrm{S}$ (SHOA 1998). The bedrock lithology under the CDI is dominated by Paleozoic metamorphic rocks, with secondary occurrences of Cretaceous granitoids and Jurassic gneiss (Sernageomin, 2003).

Almirantazgo fjord was entirely glaciated during the Last Glacial Maximum. It became ice-free either after advance $E(15,500-11,700$ cal yr BP; McCulloch et al., 2005) or about 3000 years earlier, i.e. during Henrich Stadial 1 (HS1; 18,000-14,600 cal. yr BP) according to Hall et al. (2013). The latter authors argue that the ice had retreated into Ainsworth bay by $16,800 \mathrm{cal}$ yr BP. This early retreat seems to be in agreement with the seismic interpretation of Fernandez et al. (2017), who debate the very existence of glacier advance $\mathrm{E}$, and with the data of Boyd et al. (2008), who show that Marinelli glacier had retreated into Ainsworth Bay before 12,500 cal yr BP, and reached a stable position near its 1945 terminus by 12,500 cal yr BP.

\section{Material and methods}

In 2005, a $13.45 \mathrm{~m}$ long Jumbo Piston Core (JPC67) was collected at a depth of $297 \mathrm{~m}$ in Almirantazgo fjord (54.319 ${ }^{\circ} \mathrm{S}-69.463^{\circ} \mathrm{W}$; Fig. 1) during cruise NBP0505 on board the RVIB Nathaniel B. Palmer. The core was split and described onboard and one half was sub-sampled every $10 \mathrm{~cm}$. The other half was later scanned on a Geotek MSCL core logger ( $2 \mathrm{~cm}$ resolution) at the Antarctic Research Facility (ARF, Florida State University, USA) and on an ITRAX XRF core scanner (Cox Analytical Instruments) at the Woods Hole Oceanographic Institution (MA, USA) at a resolution of $2 \mathrm{~mm}$. The XRF scanner was operated with $20 \mathrm{sec}$ scan times using a Mo X-Ray tube set to $30 \mathrm{kV}$ and $45 \mathrm{~mA}$. Additionally, the core was X-radiographed at the ARF and shell fragments were sampled for radiocarbon analysis. Subsequent measurements were made on the freeze-dried sub-samples taken every $10 \mathrm{~cm}$. These measurements included grain size, ice rafted debris content, mass-specific magnetic susceptibility, inorganic geochemistry, bulk organic geochemistry, and alkenone sea surface temperature.

Grain size was measured on the terrigenous fraction of the sediment using a Malvern Mastersizer 3000 laser grain size analyzer equipped with a Hydro MV dispersion unit. To isolate the terrigenous fraction, samples were treated with boiling $\mathrm{H}_{2} \mathrm{O}_{2}, \mathrm{HCl}$ and $\mathrm{NaOH}$ to remove organic matter and possible carbonates and biogenic silica, respectively. Prior to analysis, samples were boiled with sodium pyrophosphate $\left(\mathrm{Na}_{4} \mathrm{P}_{2} \mathrm{O}_{7} \cdot 10 \mathrm{H}_{2} \mathrm{O}\right)$ to ensure complete disaggregation of the particles. The grain size distribution of the samples was measured during $12 \mathrm{sec}$ intervals and the mode of the distributions was computed from the Mastersizer v3.5 software. We used the mode of the grain-size distributions instead of the mean to avoid the influence of ice rafted debris.

Ice Rafted Debris (IRD) was quantified using the relative percentage of particles $>150 \mu \mathrm{m}$ following Caniupán et al. (2011). The $>150 \mu \mathrm{m}$ particles were separated by wet-sieving after removal of carbonates with $10 \%$ acetic acid and organic matter with $3.5 \%$ hydrogen peroxide. IRD was counted from the $>150 \mu \mathrm{m}$ carbonate-free fraction, assuming that coarser-grained terrigenous sediment can only 
reach the core location through iceberg transport. Given the relative proximity of the glacier fronts to coring site JPC67, we opted for $>150 \mu \mathrm{m}$ instead of the sometimes used $>63 \mu \mathrm{m}$ fraction. Five (0-670 $\mathrm{cm}$ ) or $10 \mathrm{~g}$ ( $670 \mathrm{~cm}$ - bottom) of freeze-dried sediment was used for analysis. As an alternative and independent way of quantifying IRD concentrations, pebbles $(>2 \mathrm{~mm}$ ) present within $5 \mathrm{~cm}$ intervals were visually counted on the X-radiographs (Grobe, 1987; data previously published in Boyd et al., 2008). Both IRD estimates are used to assess the presence of nearby calving glaciers (Andrews, 2000).

Mass-specific magnetic susceptibility (MS) was measured with a Bartington MS2G single-frequency (1.3 $\mathrm{kHz}$ ) sensor, connected to a Bartington MS3 meter. Sediment samples were gently packed into $1 \mathrm{ml}$ LDPE vials and were analyzed in duplicate. The MS values were divided by the sample weight to obtained mass-specific MS values.

For bulk organic geochemistry, approximately $50 \mathrm{mg}$ of sediment was weighed in tin capsules, treated with $1 \mathrm{~N}$ sulphurous acid to remove possible carbonates (Verardo et al., 1990) and analyzed at the UCDavis Stable Isotope Facility. Total Organic Carbon (TOC) and the carbon stable isotopic ratio $\left(\delta^{13} \mathrm{C}\right)$ were measured by continuous flow isotope ratio mass spectrometry (CF-IRMS; 20-20 SERCON mass spectrometer) after sample combustion to $\mathrm{CO}_{2}$ and $\mathrm{N}_{2}$ at $1000^{\circ} \mathrm{C}$ in an on-line elemental analyzer (PDZEuropa ANCA-GSL). The precision, calculated by replicate analysis of an internal standard, was 0.05 $\%$ for $\delta^{13} \mathrm{C}$. The proportions and amounts of terrestrial and marine aquatic organic carbon were calculated from the TOC and $\delta^{13} \mathrm{C}$ data, using end-member values of $-19.86 \%$ (Bertrand et al., 2012b) and $-26.85 \%$ (this study; Appendix 1) for the aquatic and terrestrial sources, respectively.

A subset of 41 samples was analyzed for major and selected trace element geochemistry and carbonate content. Inorganic geochemistry was measured by ICP-AES following Bertrand et al. (2012b). In short, samples were prepared using the Li-metaborate fusion technique of Murray et al. (2000) and thirteen elements were measured on a JY Ultima C ICP-AES. Here, we report the concentrations of Ca and Sr. Analytical precision $(1 \sigma)$ for these two elements, which was calculated from the analysis of ten individually-prepared sub-samples of reference sediment PACS-2, was $0.70 \%$ for Ca and $0.82 \%$ for Sr.

The weight percentage of total inorganic carbon (TIC) of the same subset of samples was determined using an UIC CM5012 coulometer equipped with a CM5130 acidification module. For each sample, 50$60 \mathrm{mg}$ of sediment was precisely weighed into a Teflon cup, which was subsequently inserted into a glass tube and treated with $5 \mathrm{ml} \mathrm{H}_{3} \mathrm{PO}_{4} 20 \%$ to liberate $\mathrm{CO}_{2}$. This method assumes that $100 \%$ of the measured $\mathrm{CO}_{2}$ is derived from dissolution of calcium carbonate. The limit of detection was $0.04 \% \mathrm{CaCO}_{3}$.

Lipids were extracted from the sediment samples according to the method of Bligh and Dyer (1959) but substituting chloroform with dichloromethane. Sediment samples were previously spiked with nheptacosanone as a recovery standard. The lipid extracts were subjected to column chromatography and the fraction containing the C37 alkenones was concentrated and re-dissolved in isooctane with an internal standard (5-alphacholestane). Alkenones were analyzed on a Shimadzu Gas Chromatograph with a flame ionization detector (Prahl and Wakeham, 1987). C37 alkenones were identified by their retention times. The alkenone paleotemperature index $\left(\mathrm{U}^{\mathrm{K}^{\prime}}{ }_{37}\right)$ was calculated as $\mathrm{U}^{\mathrm{K}^{\prime}}{ }_{37}=(\mathrm{C} 37: 2) /(\mathrm{C} 37: 3+\mathrm{C} 37: 2)$, where $\mathrm{C} 37: 2$ and $\mathrm{C} 37: 3$ represent the di- and tri-unsaturated $\mathrm{C} 37$ 
alkenones, respectively (Brassell et al., 1986). The $\mathrm{U}^{\mathrm{k}^{\prime}}{ }_{37}$ values were converted to sea surface temperature values by applying the calibration of Prahl and Wakeham (1987; $\left.\mathrm{U}^{\mathrm{K}^{\prime}}{ }_{37}=0.033 \mathrm{~T}+0.043\right)$. The analytical error was $7 \%$.

Core chronology is based on ten carbonate shell fragments that were isolated for radiocarbon analysis (radiocarbon ages published in Boyd et al., 2008). No material suitable for dating was found below 932 $\mathrm{cm}$. The age model was constructed with CLAM 2.2 (Blaauw, 2010) and it consisted in a smooth spline (smooth factor 0.35 ) running through the 10 calibrated radiocarbon ages. Calibration curve SHCal13 (Hogg et al., 2013) was used for the entire core and a variable reservoir age reflecting the evolution of the local environment from fresh to marine water was used ( $R=0$ before 9 cal kyr $B P, R=270$ years between 9 and 8 cal kyr BP, and R=540 years after 8 kyr cal BP; De Vleeschouwer et al., in prep.). In addition, the age model takes into account the instantaneous deposition of a turbidite at 1109-1096 cm and of the sand layers at 907-898 and 629-628 cm (Fig. 2).

In addition to sediment core JPC67, we also analyzed the geochemical composition of a river sediment sample (RS09-36) collected in 2009 in the outwash plain of the western branch of Marinelli glacier (Appendix 1; Fig 1).

\section{Results}

\subsection{Lithology and chronology}

The $1345 \mathrm{~cm}$-long sediment core is composed of grey to greyish olive organic-poor homogenous fine silt. It contains one turbidite at 1109-1096 cm and three sand layers at 1201-1200.5, 907-898 and 629-628 $\mathrm{cm}$ (Fig. 2). No clear tephra layers were observed, although it is possible that the turbidite and sand layers contain some tephra material (very low abundance of glass shards). According to the age model, the core covers the last 14,300 years and accumulation rates vary between $0.4-0.8 \mathrm{~mm} / \mathrm{yr}$ during the Holocene and reach up to $7 \mathrm{~mm} / \mathrm{yr}$ during the deglaciation.

\subsection{Physical properties}

X-radiographs reveal abundant pebbles below $1100 \mathrm{~cm}$ and between 1030 and $875 \mathrm{~cm}$, in addition to a few low-abundance intervals above $800 \mathrm{~cm}$ (Fig. 3). The concentration of IRD $>150 \mu \mathrm{m}$ displays approximately the same trend, and both parameters are significantly positively correlated $(r=0.55$; p<0.001; Fig. 3).

The grain-size mode is relatively constant between 5 and $7 \mu \mathrm{m}$ throughout the core, except for two intervals at $245-215 \mathrm{~cm}$ and $160-100 \mathrm{~cm}$, where it reaches $8-9 \mu \mathrm{m}$ (Fig. 3). The 1109-1096 cm turbidite and $907-898 \mathrm{~cm}$ sand layer also clearly stand out in the grain-size mode plot.

Throughout the core, the mass-specific and volume-specific MS values are highly positively correlated $(r=0.93$; $p<0.001$; Fig. 3 ), providing evidence that changes in sediment density have a minor influence on the higher-resolution volume-specific MS values. The main increases in MS are related to the coarser 
intervals at $245-215 \mathrm{~cm}$ and $160-100 \mathrm{~cm}$. Relatively high MS values also occur at 490-475 cm, 400-285 $\mathrm{cm}$, and in the upper $20 \mathrm{~cm}$ of the core, where no clear changes in grain-size mode are visible (Fig. 3).

232

233

234

235

236

237

238

239

240

241

242

243

244

245

246

247

248

249

250

251

252

253

\subsection{Organic geochemistry}

Total organic carbon concentrations are low throughout the core (between 0.2 and $1.2 \%$ ), and they display a general increasing trend towards the upper part of the core (Fig. 4). The only two intervals where the TOC values deviate from the trend are at $245-215 \mathrm{~cm}$ and $155-110 \mathrm{~cm}$, corresponding to the coarser samples (Fig. 3). The $\delta^{13} \mathrm{C}$ data show a very similar trend, with enriched (more positive) $\delta^{13} \mathrm{C}$ values when TOC increases. End-member modeling indicates that organic matter of terrestrial origin is always present and that most changes in TOC concentrations are due to variable amounts of carbon of marine origin (Appendix 2).

\subsection{Inorganic geochemistry}

$\mathrm{XRF}$ counts for halogen elements $\mathrm{Br}$ and $\mathrm{Cl}$ are used here to assess marine organic matter concentrations in sediments (Ziegler et al., 2008) and to estimate paleosalinity, respectively. In core JPC67, both elements display roughly the same trends as TOC and $\delta^{13} \mathrm{C}$ (Fig. 4). The interpretation of $\mathrm{Br}$ counts as reflecting marine organic matter concentrations is confirmed by the significantly positive correlation between $\mathrm{Br}$ and marine $\mathrm{OC}(\mathrm{r}=0.94, \mathrm{p}<0.001)$. The similar trend in $\mathrm{Cl}$ counts suggests lower salinity conditions during the deposition of sediment with low marine organic matter concentrations.

$\mathrm{Ca}$ and $\mathrm{Sr}$ XRF counts are highly positively correlated to their concentrations measured by ICP-AES (Ca: $r=0.90, p<0.001 ; S r: r=0.96, p<0.001)$, showing that changes in physical properties have very little influence on Ca an Sr XRF core scanner intensities, in agreement with Bertrand et al. (2015). Both elements show a long-term increasing trend, punctuated by short-term increases in the coarser intervals at $245-215 \mathrm{~cm}$ and $155-110 \mathrm{~cm}$, and in the upper $30 \mathrm{~cm}$ of the sediment core. The TIC values were below detection limit throughout the core, providing evidence that the sediment does not contain any carbonate, which in turn implies that $\mathrm{Ca}$ and $\mathrm{Sr}$ variations are related to the silicate fraction.

\subsection{Alkenones}

Alkenone concentrations were only measurable above $830 \mathrm{~cm}$ (Fig. 4). They were also not detected between 790 and $760 \mathrm{~cm}$. In the rest of the core, alkenone concentrations are significantly positively correlated to the marine OC concentrations ( $r=0.59, \mathrm{p}<0.001$; Appendix 3 ). The calculated $\mathrm{U}^{\mathrm{K}^{\prime}}{ }_{37} \mathrm{SST}$ values vary between 5 and $8^{\circ} \mathrm{C}$ below $550 \mathrm{~cm}$ and average $10 \pm 0.9^{\circ} \mathrm{C}$ above, with the lowest values of the latter section occurring in the upper $30 \mathrm{~cm}$ of the sediment.

\section{Discussion}

\subsection{Proxy interpretation}

Many of the variables presented in figures 3 and 4 show clear co-variations. These variables can roughly be grouped in two main categories, which most certainly reflect two independent processes. The first 
category is defined by higher IRD, as suggested by pebble and $>150 \mu \mathrm{m}$ particle counts. Intervals rich in IRD mostly occur at the bottom of the core, below $870 \mathrm{~cm}$ (Fig. 3). The second category is represented by sediments with a higher grain-size mode, which is also reflected in high MS values and $\mathrm{Ca}$ and $\mathrm{Sr}$ concentrations, in low marine organic carbon and alkenone concentrations, and in low $\mathrm{Cl}$ counts (Figs. 3, 4; Appendix 2). The two main intervals showing these co-variations are located at $245-215 \mathrm{~cm}$ and 160 $100 \mathrm{~cm}$ (Figs. 3, 4).

Intervals with higher IRD are interpreted as reflecting the presence of glaciers calving in Almirantazgo fjord and/or in its tributary fjords and bays, which are able to produce icebergs and deliver coarse particles to coring site JPC67. Due to surface currents flowing towards the Northwest (Valdenegro and Silva 2003), it is more likely that IRD originates from the glaciers calving in Parry fjord and Ainsworth Bay than in Brookes fjord (Fig. 1). However, although several glaciers are currently calving freely in Parry fjord, and producing icebergs, no IRD was detected in the most recent sediments of core JPC67. It is likely that icebergs calving in Parry fjord melt completely before they reach site JPC67, in agreement with our field observations. Likewise, shallow sills can create significant obstructions to the transport of icebergs, preventing them from drifting freely out of the fjord (Syvitski, 1989). The latter explains why IRD is absent from the most recent part of sediment core JPC67, while Marinelli glacier is currently calving and was producing high amounts of icebergs in the 80s and 90s (Porter and Santana 2003). It appears that the shallow subaquatic arcuate moraine visible in Ainsworth bay (Fig. 1) is able to prevent icebergs from exiting the proximal basin, limiting their presence to the area between the current ice front and the arcuate moraine (Porter and Santana, 2003). Since this arcuate moraine formed during the LIA advance (Porter and Santana, 2003), it has no influence on pre-LIA IRD records. Therefore, IRD is mostly used here as an indicator of proximity to a calving glacier, instead of a simple proxy for the presence of calving glaciers.

Intervals with higher grain-size mode values, as observed at $245-215 \mathrm{~cm}$ and $160-100 \mathrm{~cm}$ (Fig. 3), are interpreted as periods of vigorous meltwater discharge. The coeval increases in $\mathrm{MS}$ and in $\mathrm{Ca}$ and $\mathrm{Sr}$ concentrations simply reflect the grain-size dependence of these three variables, as demonstrated by the results obtained on proglacial river sediment sample RS09-36 (Appendix 1). In RS09-36, MS, Ca, and $\mathrm{Sr}$ indeed peak in the fine and medium silt fractions, due to mineralogical sorting (Appendix 1). Since carbonate concentrations were always below detection limit, changes in Ca and Sr concentrations only reflect changes in the silicate fraction and their high concentrations seem to result from higher pyroxene abundance in fine and medium silts (Appendix 1). The interpretation of the higher grain-size mode values as representing vigorous meltwater discharge is confirmed by the concomitant decrease in aquatic carbon of marine origin (Fig. 4; Appendix 2), representing dilution by a higher supply of terrigenous particles. In the two intervals at $245-215 \mathrm{~cm}$ and $160-100 \mathrm{~cm}$, organic matter concentrations and stable isotopic composition are essentially the same as in Marinelli proglacial sediment sample RS09-36 (TOC=0.43\%; $\delta^{13} \mathrm{C}=-26.85 \%$; Fig. 4; Appendix 1), highlighting the predominantly terrestrial origin of the sediment in these two intervals. Our interpretation is further supported by the concomitant decrease in $\mathrm{Cl}$ XRF counts and by the extreme drop in alkenone concentrations (Fig. 4), indicating a freshening of the fjord waters. 


\subsection{Deglaciation}

304

305

306

307

308

309

310

311

312

313

314

315

316

317

318

319

320

321

322

323

324

325

326

327

328

329

330

331

332

333

334

335

336

337

338

339

340
Following the interpretation of the sediment proxies in the previous section, the most indicative variables are presented versus age in figure 5. Sedimentation in core JPC67 starts at 14,300 cal yr BP with IRD-rich and organic-poor sediments interpreted as glacier-proximal deposits. Given that the core did not penetrate the entire sediment infill of Almirantazgo fjord (Boyd et al., 2008), the deglaciation of Almirantazgo fjord must have occurred prior to $14,300 \mathrm{cal}$ yr BP, in agreement with Boyd et al. (2008) and with the recent hypothesis that $\mathrm{CDI}$ glaciers extensively retreated from their ultimate LGM advance during HS1 (18,000-14,600 cal yr BP; Hall et al., 2013). The existence of a glacier in Almirantazgo fjord until 15,500-11,700 cal yr BP, as suggested by McCulloch et al. (2005), is unlikely.

The high abundance of IRD, the absence of alkenones, and the very high accumulation rates until 13,500 cal yr BP (Fig. 5) indicate the presence of glaciers calving near coring site JPC67, as expressed by Boyd et al. (2008). At 13,500 cal yr BP, IRD disappears and alkenones start to be detected in the sediment (Fig. 5 ), indicating that the glaciers had shrunk significantly and that Almirantazgo fjord was an open fjord environment. The presence of high amounts of IRD immediately prior to 13,500 cal yr BP (Fig. 5) suggests that glaciers shrank due to rapid calving. Glaciers likely re-advanced slightly at $13,100-12,300$ cal yr BP, as indicated by the presence of IRD, but certainly not as far as prior to 13,500 cal yr BP.

By 12,300 cal yr BP, ice fronts were likely near their present-day termini, in agreement with Boyd et al. (2008). Almirantazgo fjord, however, only became a predominantly saline fjord environment with nearmodern oceanographic conditions by $9800 \mathrm{cal}$ yr BP, as indicated by the significant increase in SST and to a lesser extent - in organic carbon of marine origin (Fig. 5). This timing corresponds remarkably well to the early Holocene sea level rise (Fig. 6; Sidall et al., 2003; Smith et al., 2011) and likely reflects the arrival of warmer marine waters from the South Atlantic over the $\sim 60 \mathrm{~m}$ deep sill at Primera Angostura, as suggested by Aracena et al. (2015). After $9800 \mathrm{cal} \mathrm{yr} \mathrm{BP,} \mathrm{Almirantazgo} \mathrm{fjord} \mathrm{became} \mathrm{a} \mathrm{typical} \mathrm{marine}$ fjord environment, affected by meltwater inputs from CDI glaciers.

\subsection{Holocene variability of CDI outlet glaciers}

During the last 9800 years, CDI outlet glaciers did not re-advance near their deglacial position. Although our Almirantazgo fjord sediment record does not show any major IRD-rich interval during the Holocene, it clearly suggests the presence of two vigorous meltwater events at 3250-2700 and 2000-1200 cal yr $\mathrm{BP}$, marked by clear increases in grain-size mode and MS, and by the substantial dilution of organic carbon of marine origin by detrital sediment input (Fig. 5). The latter interpretation is also confirmed by the general increase in accumulation rates at $3000-1000$ cal yr BP (Fig. 5), which is likely due to the two events but could not be better temporally resolved due to the relatively low number of samples available for radiocarbon analysis in core JPC67. Interestingly, the sediment record shows the presence of low but significant amounts of IRD at $2700 \mathrm{cal}$ yr BP, suggesting that some glaciers re-advanced to a calving position between the two melting events.

In addition to these two clearly-marked events, meltwater input may also have increased around 87508000 and 5600-3750 cal yr BP, as marked by higher MS values and slightly lower amounts of aquatic carbon of marine origin. The sedimentary signature of these two intervals is very similar to the 
variations observed for the last few decades, which are also marked by higher MS and slightly lower marine organic carbon concentrations, but for which no clear increase in grain-size mode was observed (Fig. 5). The absence of variations in grain-size and accumulation rates likely reflects the trapping of sediment behind shallow sills in glacier-proximal basins, similar to what is currently occurring behind the arcuate LIA moraine of Marinelli glacier (Koppes et al., 2009).

During the last 9800 years, alkenone SSTs oscillate around $10^{\circ} \mathrm{C}$, although the exact values are much more variable after 4000 cal yr BP than before (Fig. 5). During the last 4000 years, particularly low values occur at 3500-3300 cal yr BP and during the most recent decades, and high values persisted between 2400 and $1600 \mathrm{cal}$ yr BP. Since SSTs in fjord environments are influenced by marine water circulation and meltwater input, it is complicated to tell these two processes apart, but it is likely that the abrupt increases in SST around 3300-3200 and 2400-2200 cal yr BP participated in triggering the long-lasting meltwater events at 3250-2700 and 2000-1200 cal yr BP, respectively. The subsequent abrupt drop in SST in 1600 cal yr BP likely represents the cooling of the fjord waters, with a slight delay, due to the increase in meltwater input. It is interesting to note that, although alkenones are similarly diluted by both meltwater events (Fig. 4; Appendix 3), SSTs only drop during/after the second event (Fig. 5), suggesting that the 2000-1200 cal yr BP meltwater event was larger in magnitude than its predecessor. Finally, the marked cooling of the last $~ 800$ years may have very little to do with meltwater input and may rather represent the regional decrease in ocean temperatures during the last 900 years (Caniupán et al., 2014).

\subsection{Comparison with other glacier variability records in southernmost Patagonia}

Only two reconstructions of CDI glacier variability during the Holocene have been published. The first concerns glaciers reaching Pia bay, which is located on the southern flank of the icefield (Fig. 1), and it is based on radiocarbon-dated peat deposits developed in a former outwash plain (Kuylenstierna et al., 1996). The second consists of radiocarbon-dated moraine deposits in the Ema glacier valley (Monte Sarmiento; Fig. 1; Strelin et al., 2008).

In Pia bay, Kuylenstierna et al. (1996) identified three glacier maxima - before 3200 cal yr BP, prior to $800 \mathrm{cal} \mathrm{yr} \mathrm{BP}$ and between 800 and $600 \mathrm{cal} \mathrm{yr} \mathrm{BP} \mathrm{(Fig.} \mathrm{5).} \mathrm{These} \mathrm{glacier} \mathrm{advances} \mathrm{are} \mathrm{entirely} \mathrm{compatible}$ with our Almirantazgo fjord sediment records since the first one occurs immediately prior to our first meltwater event at 3250-2700 cal yr BP, and later advances are posterior to our second meltwater event (Fig 5).

The record of Strelin et al. (2008) suggests a possible glacier advance at 6800-5700 cal yr BP, and shows four well-marked advances - shortly before $3300 \mathrm{cal} \mathrm{yr} \mathrm{BP,} \mathrm{at} 1170 \mathrm{cal}$ yr BP, shortly after $620 \mathrm{cal}$ yr BP and between 400 and $100 \mathrm{cal}$ yr BP. The timing of the advance shortly before $3300 \mathrm{cal}$ yr BP is strikingly similar to the advance in Pia bay before $3200 \mathrm{cal} \mathrm{yr} \mathrm{BP,} \mathrm{and} \mathrm{is} \mathrm{therefore} \mathrm{in} \mathrm{good} \mathrm{agreement} \mathrm{with} \mathrm{our}$ record as well. It is noteworthy that these two advances correspond to the lowest SST in Almirantzgo fjord during the Holocene, suggesting that it may have been caused by a regional cooling. This cooling is however not reflected in the more marine records of Caniupán et al. (2014). The three advances that occurred after $1200 \mathrm{cal}$ yr BP post-date our second meltwater event. The presence of low but significant 
amounts of IRD in our sediment record at 1100-1000 cal yr BP (Fig. 5) indicates that some of the northern CDI glaciers also re-advanced to a calving position after the second meltwater event.

An interesting observation is the apparent lack of glacier re-advance in Pia bay and in Ema glacier valley between 2700 and 2000 cal. yr BP (i.e., between the two meltwater events identified in sediment core JPC67), although our sediment record shows the presence of IRD. One possible explanation is that the southern and western CDI glaciers responded differently to changes in climate, due to their orientation with respect to the southern westerly winds, as suggested by Holmund and Fuenzalida (1995).

Holocene variations in NPI and SPI glaciers have been studied in much more detail than for CDI glaciers. For the SPI, two schemes were proposed over the last decades (Glasser et al., 2004): the Mercer scheme, with three Neoglacial advances during the last 5000 years (Mercer, 1982); and the Aniya scheme with four advances during the same time interval (Aniya, 1995; 1996). In a recent review of Holocene SPI glacier advances, Aniya (2013) proposed a new scheme that combines the two previous chronologies. The latter contains five Neoglacial advances labelled from I to $V$ at 5130-4430 cal yr BP, 3850-3490 cal yr BP, 2770-1910 cal yr BP, 1450-750 cal yr BP, and 350-50 cal yr BP (Fig. 5; ages calibrated from Aniya 2013 using SHCal13). According to Aniya (2013), the most robust of these five advances, i.e., the intervals common to both original schemes, are advances III (2770-1910 cal yr BP) and V (17-19 th centuries). The most recent findings of Strelin et al. (2014) and Kaplan et al. (2016) for the eastern side of the SPI are in general agreement with Aniya's chronology. Masiokas et al. (2009), however, suggested that in southern Patagonia, including Cordillera Darwin, the latest (LIA) advance could have occurred 1 to 3 centuries prior to the $19^{\text {th }}$ century.

The timing of SPI advances II, IV and V corresponds reasonably well to the CDI advances described by Kuylenstierna et al. (1996) and Strelin et al. (2008) (Fig. 5). Although these authors did not describe any CDI glacier advance at 2770-1910 cal yr BP (Neoglacial advance III), our Almirantazgo sediment record suggests that Neoglacial advance III also affected CDI glaciers, providing evidence that CDI and SPI glaciers varied in phase during most of the Neoglaciation. Only Neoglacial advance I does not seem to be recorded in any of the $\mathrm{CDI}$ records. In addition, it is important to note that our two vigorous meltwater events at 3250-2700 and 2000-1200 cal yr BP occur exactly in-between glacier advances II-III, and IIIIV, respectively (Fig. 5). This observation suggests that CDI glaciers shrank and re-advanced rapidly during the late Holocene.

Prior to the Neoglaciation, the timing of SPI glacier advances is less consistent in the literature, with Aniya (2013) arguing for two possible advances at 8980-7610 (or 8270) cal yr BP and 6440-5680 cal yr BP, and Kaplan et al. (2016) describing an advance of eastern SPI glaciers at $6120 \pm 390 \mathrm{cal}$ yr BP. Although the latter may have occurred in the CDI as well, as suggested by Strelin et al. (2008; possible advance at 6800-5700 cal yr BP), our sediment record does not show any IRD during that time interval, suggesting that if glaciers indeed grew, their advance was less extensive than during the Neoglaciation. The occurrence of very low MS values and of the lowest sediment accumulation rates of core JPC67 around $7300-5700$ cal yr BP seems to confirm the absence of melting glaciers during that time interval. Therefore, it is likely that CDI glaciers were land-based and slightly advancing at 7300-5700 cal yr BP. 
Overall, however, CDI glaciers were much more stable during the first part of the Holocene than during the Neoglaciation.

420 The meltwater events identified in sediment core JPC67 seem to have influenced nearby marine and

421 terrestrial environments.

422 In sediment core MD07-3132, which is located in the central basin of the Strait of Magellan nearly 100

$423 \mathrm{~km}$ to the northwest of JPC67 (Fig. 1), Aracena et al. (2015) described a period of particularly low

424 carbonate productivity between 3200 and 2400 cal yr BP. This interval corresponds particularly well with

425 the timing of the first meltwater event detected in sediment core JPC67 at 3250-2700 cal yr BP (Fig. 7).

426 We suggest that, although productivity in the central basin of the Strait of Magellan was already low

427 during the entire Neoglaciation, the first large CDI meltwater event at 3250-2700 cal yr BP put

428 additional stress on carbonate organisms and reduced light penetration, causing fjord productivity to

429 drop by a factor of three.

430

431

432

433

434

435

436

437

438

439

440

441

442

443

444

445

446

447

448

449

450

451

452

Similarly, outwash sediments are known to act as efficient dust sources, especially on glacial-interglacial timescales. Sugden et al. (2009), for example, showed that for the last 80,000 years, dust peaks in Antarctica coincided with periods of proglacial outwash sediment deposition in Patagonia. At the scale of the Holocene, Patagonian glacier variability also seems to affect dust production, as recently proposed by Vanneste et al. (2016). These authors identified relatively high dust accumulation rates in Karukinka, i.e., immediately across Almirantazgo fjord (Fig. 1) between 3100 and 1200 cal yr BP, peaking at 1900-1200 cal yr BP (Fig. 7). This peak corresponds remarkably well to the timing of our second meltwater event at 2000-1200 cal yr BP, providing additional evidence that CDI glaciers retreated rather far landward at that time to allow the formation of extensive outwash plains. In addition, the onset of the increase in dust accumulation visible in the Karukinka peat record at 3100 cal yr BP coincides with the beginning of the first meltwater event. Therefore, we suggest that CDI glaciers shrank enough to form outwash plains during both meltwater events, but that glaciers shrank further during the second event, resulting in the formation of extensive outwash plains. These large exposed outwash plains provided fine-grained material available to be picked up by wind, as confirmed by the provenance study of Vanneste et al. (2016).

\section{Conclusions}

Sediment core JPC67 contains a continuous record of northern CDI glacier variability during the last 14,300 years. The age of the bottom of the core provides evidence that the deglaciation of Almirantazgo fjord occurred prior to 14,300 cal yr BP. The fjord remained a typical proglacial environment dominated by freshwater conditions until $9800 \mathrm{cal}$ yr BP, with glacier-proximal conditions progressively disappearing after 13,500 cal yr BP. Almirantazgo fjord only became marine-dominated with oceanographic conditions similar to the present-day after the early Holocene sea-level rise at $9800 \mathrm{cal}$ yr BP. 
During the first half of the Holocene, our results show that glaciers were land-locked and relatively stable, except for a potential advance within land-based locations from 7300 to 5700 cal yr BP. In comparison, CDI glaciers re-advanced and shrank back much more rapidly during the Neoglaciation, and these variations were mostly in phase with SPI glaciers. Of the five SPI Neoglacial advances described in the literature, only the first one (5130-4430 cal yr BP) is not expressed in Almirantazgo fjord sediments. In addition, our sediment record clearly shows that CDI outlet glaciers melted rapidly at 3250-2700 and 2000-1200 cal yr BP, but re-advanced to calving locations relatively soon afterwards (Neoglacial III and IV). These two melting events affected fjord productivity up to $100 \mathrm{~km}$ to the north of the CDI, and they exposed large outwash plains that acted as a source of dust for the Tierra del Fuego area, especially during the second event.

Our results highlight the potential of fjord sediments to reconstruct glacier variability at high resolution over multi-millennial timescales. Compared to traditional archives of glacier mass balance, they offer the advantage of continuously recording melting events and calving-land based transitions. We argue that fjord sediments should be increasingly used to reconstruct the evolution of mid and high-latitude glaciers, in addition to geomorphic mapping and exposure dating.

\section{Acknowledgements}

Cruise NBP0505 was funded by the National Science Foundation, Office of Polar Programs grant NSF/OPP 03-38137 to John Anderson and Julia Smith Wellner. The captain and crew of the RV/IB Nathaniel B. Palmer are acknowledged for their support during the cruise. We are grateful to Liviu Giosan (WHOI) and to Tim Ferdelman, Andrea Schipper and Thomas Max (MPI, Bremen) for providing access to the ITRAX XRF core scanner and UIC coulometer, respectively. We also warmly thank Reinout Debergh, Julian Janocha and Alvaro del Rey for processing some of the sediment samples for IRD and grain-size analysis during their studies at Ghent University. Brandi Boyd kindly provided the pebble count data and Lilian Núñez (UdeC) processed the sediment samples for alkenone analysis. Toon Van Dijck and Nathalie Fagel facilitated the acquisition of the XRD results presented in appendix. This research was supported by an EU Marie Curie FP6 postdoctoral fellowship to S.B., by National Geographic Grant 8379-07 (to S.B.), by COPAS Center FONDAP Grant 150100007 and COPAS Sur-Austral CONICYT PIA PFB31 (to C.L and S.P), and by IDEAL Center FONDAP Grant 15150003 (to C.L.). Samples were provided by the Antarctic Marine Geology Research Facility at Florida State University. We thank the facility curators for their assistance with shipping core JPC67 to WHOI. Finally, Mahyar Mohtadi (MARUM) and Rodrigo Fernandez (UT Austin) are thanked for constructive discussions at various stages of this project.

\section{References}

Andresen, C.S., Straneo, F., Ribergaard, M.H., Bjørk, A.A., Andersen, T.J., Kuijpers, A., NørgaardPedersen, N., Kjær, K.H., Schjøth, F., Weckström, K., Ahlstrøm, A.P., 2011. Rapid response of Helheim Glacier in Greenland to climate variability over the past century. Nature Geoscience 5, 37-41.

Andrews, J.T., 2000. Icebergs and iceberg rafted detritus (IRD) in the North Atlantic: facts and assumptions. Oceanography 13, 100-108. 
Aniya, M., 1995. Holocene glacial chronology in Patagonia: Tyndall and Upsala Glaciers. Arctic and Alpine Research 27 (4), 311-322.

Aniya, M., 1996. Holocene variations of Ameghino Glacier, southern Patagonia. The Holocene 6, 247252.

Aniya, M., 2013. Holocene glaciations of Hielo Patagonico (Patagonia Icefield), South America: A brief review. Geochemical Journal 47, 97-105.

Aracena, C., Kilian, R., Lange, C.B., Bertrand, S., Lamy, F., Arz, H.W., De Pol-Holz, R., Baeza, O., Pantoja, S., Kissel, C., 2015. Holocene variations in productivity associated with changes in glacier activity and freshwater flux in the central basin of the Strait of Magellan. Palaeogeography, Palaeoclimatology, Palaeoecology 436, 112-122.

Bertrand, S., Hughen, K., Giosan, L., 2015. Limited Influence of Sediment Grain Size on Elemental XRF Core Scanner Measurements, in: Croudace, I.W., Rothwell, R.G. (Eds.), Micro-XRF Studies of Sediment Cores, pp. 473-490.

Bertrand, S., Hughen, K.A., Lamy, F., Stuut, J.B.W., Torrejón, F., Lange, C.B., 2012a. Precipitation as the main driver of Neoglacial fluctuations of Gualas glacier, Northern Patagonian Icefield. Climate of the Past 8, 519-534.

Bertrand, S., Hughen, K.A., Sepúlveda, J., Pantoja, S., 2012b. Geochemistry of surface sediments from the fjords of Northern Chilean Patagonia (44-47오): Spatial variability and implications for paleoclimate reconstructions. Geochimica Et Cosmochimica Acta 76, 125-146.

Blaauw, M., 2010. Methods and code for 'classical' age-modelling of radiocarbon sequences. Quaternary Geochronology 5, 512-518.

Bligh, E. G., Dyer, W. J., 1959. A rapid method of total lipid extraction and purification. Journal of Biochemistry and Physiology 37, 911-917.

Bown, F., Rivera, A., Zenteno, P., Bravo, C., Cawkwell, F., 2014. First Glacier Inventory and Recent Glacier Variation on Isla Grande de Tierra Del Fuego and Adjacent Islands in Southern Chile, in: Kargel, J.S., Leonard, G.J., Bishop, M.P., Kääb, A., Raup, B.H. (Eds.), Global Land Ice Measurements from Space, pp. 661-674.

Boyd, B.L., Anderson, J.B., Wellner, J.S., Fernández, R.A., 2008. The sedimentary record of glacial retreat, Marinelli Fjord, Patagonia: Regional correlations and climate ties. Marine Geology 255, 165-178.

Brassell, S.C., Eglinton, G., Marlowe, I.T., Pflaumann, U., Sarnthein, M., 1986. Molecular stratigraphy: a new tool for climatic assessment. Nature 320, 129-133.

Caniupán, M., Lamy, F., Lange, C.B., Kaiser, J., Arz, H., Kilian, R., Baeza Urrea, O., Aracena, C., Hebbeln, D., Kissel, C., Laj, C., Mollenhauer, G., Tiedemann, R., 2011. Millennial-scale sea surface temperature and Patagonian Ice Sheet changes off southernmost Chile $\left(53^{\circ} \mathrm{S}\right)$ over the past $\sim 60 \mathrm{kyr}$. Paleoceanography 26.

Caniupán, M., Lamy, F., Lange, C.B., Kaiser, J., Kilian, R., Arz, H.W., León, T., Mollenhauer, G., Sandoval, S., De Pol-Holz, R., Pantoja, S., Wellner, J., Tiedemann, R., 2014. Holocene sea-surface temperature variability in the Chilean fjord region. Quaternary Research 82, 342-353.

Davies, B.J., Glasser, N.F., 2012. Accelerating shrinkage of Patagonian glaciers from the Little Ice Age ( AD 1870) to 2011. Journal of Glaciology 58, 1063-1084. 
Fernández, R., Gulick, S., Rodrigo, C., Domack, E., Leventer, A., 2017. Seismic stratigraphy and glacial cycles in the inland passages of the Magallanes Region of Chile, southernmost South America. Marine Geology 386, 19-31.

Fernandez, R.A., Anderson, J.B., Wellner, J.S., Hallet, B., 2011. Timescale dependence of glacial erosion rates: A case study of Marinelli Glacier, Cordillera Darwin, southern Patagonia. Journal of Geophysical Research: Earth Surface 116.

Garreaud, R., Lopez, P., Minvielle, M., Rojas, M., 2013. Large-Scale Control on the Patagonian Climate. Journal of Climate 26, 215-230.

Glasser, N.F., Harrison, S., Jansson, K.N., Anderson, K., Cowley, A., 2011. Global sea-level contribution from the Patagonian Icefields since the Little Ice Age maximum. Nature Geoscience 4, 303-307.

Glasser, N.F., Harrison, S., Winchester, V., Aniya, M., 2004. Late Pleistocene and Holocene palaeoclimate and glacier fluctuations in Patagonia. Global and Planetary Change 43, 79-101.

Grobe, H., 1987. A simple method for the determination of ice-rafted debris in sediment cores. Polarforschung 57, 123-126.

Hall, B.L., Porter, C.T., Denton, G.H., Lowell, T.V., Bromley, G.R.M., 2013. Extensive recession of Cordillera Darwin glaciers in southernmost South America during Heinrich Stadial 1. Quaternary Science Reviews, 62, 49-55.

Hogg, A.G., Hua, Q., Blackwell, P.G., Niu, M., Buck, C.E., Guilderson, T.P., Heaton, T.J., Palmer, J.G., Reimer, P.J., Reimer, R.W., Turney, C.S.M., Zimmerman, S.R.H., 2013. SHCal13 Southern Hemisphere Calibration, 0-50,000 Years Cal BP. Radiocarbon 55, 1889-1903.

Holmlund, P., Fuenzalida, H., 1995. Anomalous glacier responses to 20th century climatic changes in Darwin Cordillera, southern Chile. Journal of Glaciology 41, 465-473.

Howe, J.A., Austin, W.E.N., Forwick, M., Paetzel, M., 2010. Fjord Systems and Archives. Geological Society, London.

Kaplan, M.R., Schaefer, J.M., Strelin, J.A., Denton, G.H., Anderson, R.F., Vandergoes, M.J., Finkel, R.C., Schwartz, R., Travis, S.G., Garcia, J.L., Martini, M.A., Nielsen, S.H.H., 2016. Patagonian and southern South Atlantic view of Holocene climate. Quaternary Science Reviews 141, 112-125.

Koppes, M., Hallet, B., Anderson, J., 2009. Synchronous acceleration of ice loss and glacial erosion, Glaciar Marinelli, Chilean Tierra del Fuego. Journal of Glaciology 55, 207-220.

Koppes, M., Hallet, B., Rignot, E., Mouginot, J., Wellner, J. S., Boldt, K., 2015. Observed latitudinal variations in erosion as a function of glacier dynamics. Nature 526(7571), 100-103.

Kuijpers, A., Knutz, P., Moros, M., 2014. Ice-Rafted Debris (IRD), in: Harff, J., Meschede, M., Petersen, S., Thiede, J. (Eds.), Encyclopedia of Marine Geosciences, pp. 359-363.

Kuylenstierna, J.L., Rosqvist, G.C., Holmlund, P., 1996. Late-Holocene glacier variations in the Cordillera Darwin, Tierra del Fuego, Chile. The Holocene 6, 353-358.

Lemke, P., Ren, J., Alley, R.B., Allison, I., Carrasco, J., Flato, G., Fujii, Y., Kaser, G., Mote, P., Thomas, R.H., Zhang, T., 2007. Observations: Changes in Snow, Ice and Frozen Ground, in: Solomon, S., Qin, D., Manning, M., Chen, Z., Marquis, M., Averyt, K.B., Tignor, M., Miller, H.L. (Eds.), Climate Change 2007: The Physical Science Basis. Contribution of Working Group I to the Fourth Assessment Report of the Intergovernmental Panel on Climate Change. Cambridge University Press, Cambridge, United Kingdom and New York, NY, USA, pp. 337-383. 
Lenaerts, J.T.M., van den Broeke, M.R., van Wessem, J.M., van de Berg, W.J., van Meijgaard, E., van Ulft, L.H., Schaefer, M., 2014. Extreme Precipitation and Climate Gradients in Patagonia Revealed by HighResolution Regional Atmospheric Climate Modeling. Journal of Climate 27, 4607-4621.

Lopez, P., Chevallier, P., Favier, V., Pouyaud, B., Ordenes, F., Oerlemans, J., 2010. A regional view of fluctuations in glacier length in southern South America. Global and Planetary Change 71, 85-108.

Masiokas, M.H., Rivera, A., Espizua, L.E., Villalba, R., Delgado, S., Aravena, J.C., 2009. Glacier fluctuations in extratropical South America during the past 1000 years. Palaeogeography, Palaeoclimatology, Palaeoecology 281, 242-268.

McCulloch, R.D., Fogwill, C.J., Sugden, D.E., Bentley, M.J., Kubik, P.W., 2005. Chronology of the Last Glaciation in Central Strait of Magellan and Bahía Inútil, Southernmost South America. Geografiska Annaler: Series A, Physical Geography 87, 289-312.

Melkonian, A.K., Willis, M.J., Pritchard, M.E., Rivera, A., Bown, F., Bernstein, S.A., 2013. Satellite-derived volume loss rates and glacier speeds for the Cordillera Darwin Icefield, Chile. The Cryosphere 7, 823839.

Mercer, J.H., 1982. Holocene glacier variations in southern South America. Striae 18, 35-40.

Moffat, C., 2014. Wind-driven modulation of warm water supply to a proglacial fjord, Jorge Montt Glacier, Patagonia. Geophysical Research Letters 41, 3943-3950.

Murray, R., Miller, D., Kryc, K., 2000. Analysis of major and trace elements in rocks, sediments, and interstitial waters by inductively coupled plasma-atomic emission spectrometry (ICP-AES). ODP Technical Note, pp. 1-27.

Porter, C., Santana, A., 2003. Rapid 20th century retreat of Ventisquero Marinelli in the Cordillera Darwin Icefield. Anales del Instituto de la Patagonia 31, 17-26.

Prahl, F.G., Wakeham, S.G., 1987. Calibration of unsaturation patterns in long-chain ketone compositions for palaeotemperature assessment. Nature 330, 367-369.

Rignot, E., Rivera, A., Casassa, G., 2003. Contribution of the Patagonia Icefields of South America to sea level rise. Science 302, 434-437.

Sernageomin, 2003. Mapa geologico de Chile version digital, escala 1/1.000.000.

SHOA, 1998. Bahia Inutil a Seno Almirantazgo y Acceso norte al Canal Magdalena. Mapa batimetrico escala $1 / 200.000$.

Siddall, M., Rohling, E.J., Almogi-Labin, A., Hemleben, C., Meischner, D., Schmelzer, I., Smeed, D.A., 2003. Sea-level fluctuations during the last glacial cycle. Nature 423, 853-858.

Smith, D.E., Harrison, S., Firth, C.R., Jordan, J.T., 2011. The early Holocene sea level rise. Quaternary Science Reviews 30, 1846-1860.

Strelin, J., Casassa, G., Rosqvist, G., Holmlund, P., 2008. Holocene glaciations in the Ema Glacier valley, Monte Sarmiento Massif, Tierra del Fuego. Palaeogeography, Palaeoclimatology, Palaeoecology 260, 299-314.

Strelin, J.A., Kaplan, M.R., Vandergoes, M.J., Denton, G.H., Schaefer, J.M., 2014. Holocene glacier history of the Lago Argentino basin, Southern Patagonian Icefield. Quaternary Science Reviews 101, 124-145.

Sugden, D.E., McCulloch, R.D., Bory, A.J.M., Hein, A.S., 2009. Influence of Patagonian glaciers on Antarctic dust deposition during the last glacial period. Nature Geoscience 2, 281-285. 
Syvitski, J.P.M., 1989. On the Deposition of Sediment within Glacier-Influenced Fjords - Oceanographic Controls. Marine Geology 85, 301-329.

Valdenegro, A., Silva, N., 2003. Caracterización oceanográfica física y química de la zona de canales y fiordos australes de Chile entre el estrecho de Magallanes y cabo de Hornos (Cimar 3 Fiordos). Ciencia y tecnología del Mar 26, 19-60.

Vanneste, H., De Vleeschouwer, F., Bertrand, S., Martínez-Cortizas, A., Vanderstraeten, A., Mattielli, N., Coronato, A., Piotrowska, N., Jeandel, C., Roux, G.L., 2016. Elevated dust deposition in Tierra del Fuego (Chile) resulting from Neoglacial Darwin Cordillera glacier fluctuations. Journal of Quaternary Science 31, 713-722.

Verardo, D.J., Froelich, P.N., Mcintyre, A., 1990. Determination of Organic-Carbon and Nitrogen in Marine-Sediments Using the Carlo-Erba-Na-1500 Analyzer. Deep-Sea Research 37, 157-165.

Walker, M.J.C., Berkelhammer, M., Björck, S., Cwynar, L.C., Fisher, D.A., Long, A.J., Lowe, J.J., Newnham, R.M., Rasmussen, S.O., Weiss, H., 2012. Formal subdivision of the Holocene Series/Epoch: a Discussion Paper by a Working Group of INTIMATE (Integration of ice-core, marine and terrestrial records) and the Subcommission on Quaternary Stratigraphy (International Commission on Stratigraphy). Journal of Quaternary Science 27, 649-659.

Ziegler, M., Jilbert, T., de Lange, G.J., Lourens, L.J., Reichart, G.-J., 2008. Bromine counts from XRF scanning as an estimate of the marine organic carbon content of sediment cores. Geochemistry, Geophysics, Geosystems 9. 


\section{Figure captions}

632 Figure 1 - Location of sediment core JPC67 in Almirantazgo fjord. The other records discussed in the 633 paper are also indicated: sediment core MD07-3121 (Aracena et al., 2015); Karukinka peatbog (Vanneste 634 et al., 2016); Pia bay (Kuylenstierna et al., 1996) and Ema glacier (Strelin et al., 2008). The yellow circle 635 labeled RS09-36 represents a river sediment sample collected in the outwash plain of the northern 636 branch of Marinelli glacier (see Appendix 1). NPI: Northern Patagonian Icefield; SPI: Southern Patagonian 637 Icefield; CDI: Cordillera Darwin Icefield.

638 Figure 2 - Chronology of sediment core JPC67. The CLAM age model is based on the ten radiocarbon 639 ages published in Boyd et al. (2008).

640 Figure 3 - Physical properties measured on sediment core JPC67. Note that magnetic susceptibility was 641 measured both on the split core surface (volume-specific; $2 \mathrm{~cm}$ resolution) and on discrete samples 642 (mass-specific; $10 \mathrm{~cm}$ resolution) to assess the influence of sediment density and water content on the 643 high-resolution volume-specific measurements.

644 Figure 4 - Selected organic and inorganic geochemical parameters measured on sediment core JPC67.

645 For the high-resolution XRF core scanner measurements ( $\mathrm{Br}, \mathrm{Cl}, \mathrm{Ca}$ and $\mathrm{Sr}$ ), the raw data ( $2 \mathrm{~mm}$ 646 resolution) are presented in grey and the colored curves correspond to running averages over $20 \mathrm{~cm}$ 647 (101 datapoints).

648 Figure 5 - Summary of the most indicative variables measured on sediment core JPC67 versus age. The 649 horizontal orange rectangles represent meltwater intervals of proximal (dark) and more distal (light) 650 glaciers. Neoglacial advances of CDI glaciers are indicated to the right of the figure: Pia bay from 651 Kuylenstierna et al. (1996), and Ema glacier from Strelin et al. (2008). The five Neoglaclacial advances 652 recognized for SPI glaciers by Aniya (2013) are also indicated. ACR and YD stand for Antarctic Cold 653 Reversal and Younger Dryas, respectively. The sub-divisions of the Holocene are from Walker et al. 654 (2012).

655 Figure 6 -Comparison between the alkenone SST values measured on sediment core JPC67 and the 656 global sea-level rise curve of Siddal et al. (2003). The transgression from the South Atlantic likely 657 occurred when sea level reached $\sim 60 \mathrm{~m}$, which corresponds to the depth of the sill at Primera Angostura 658 in the Strait of Magellan.

659 Figure 7 - Influence of rapidly shrinking CDI glaciers between Neoglacial advances II-III and III-IV on 660 regional marine and terrestrial environments. Carbonate accumulation rates in sediment core MD076613132 (central basin of the Strait of Magellan, see Fig. 1) are from Aracena et al. (2015), and the dust flux 662 in Karukinka peatbog, which is located immediately across Almirantazgo fjord (Fig. 1), is from Vanneste 663 et al. (2016). 


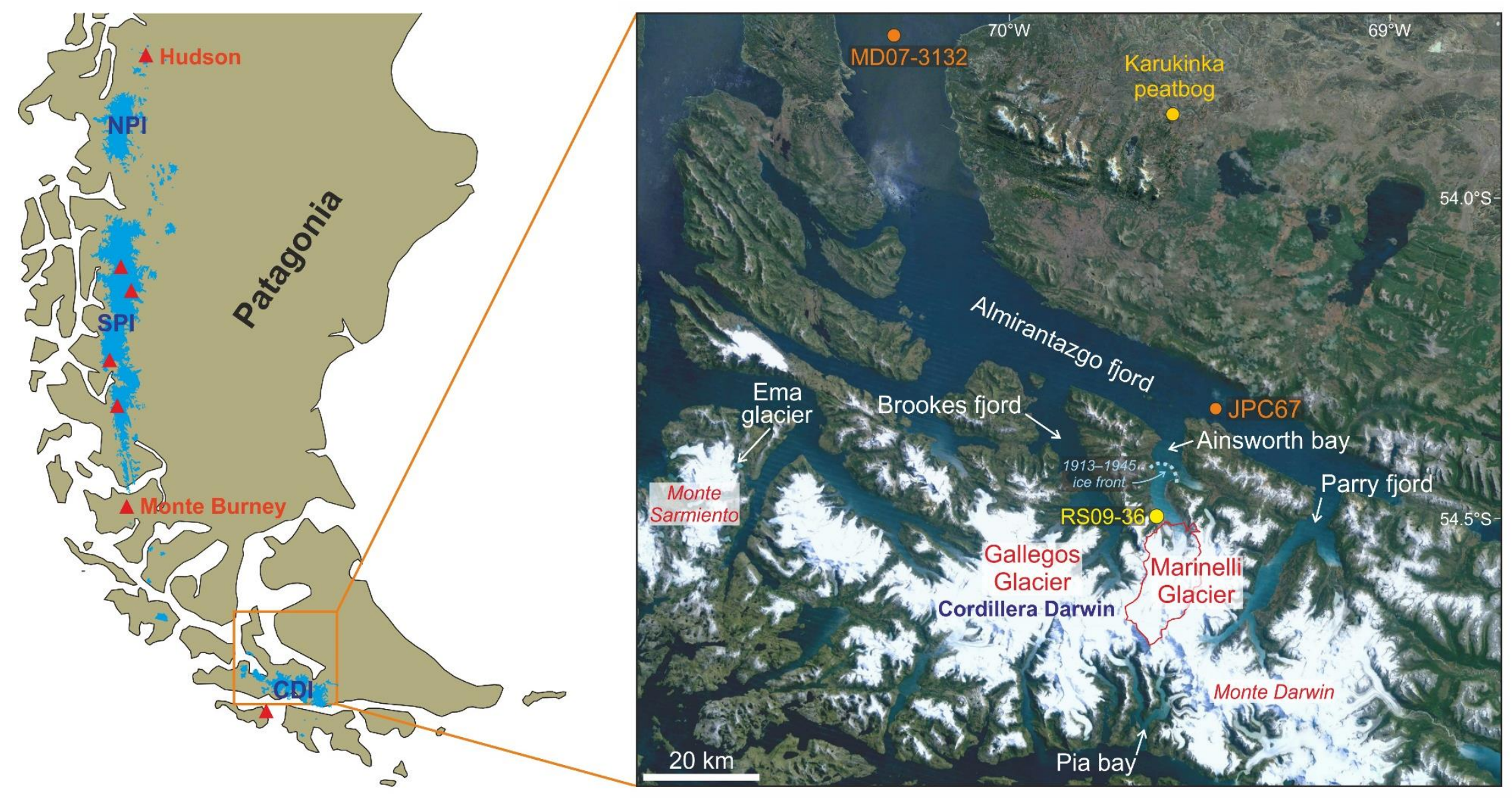

Bertrand et al - Figure 1 


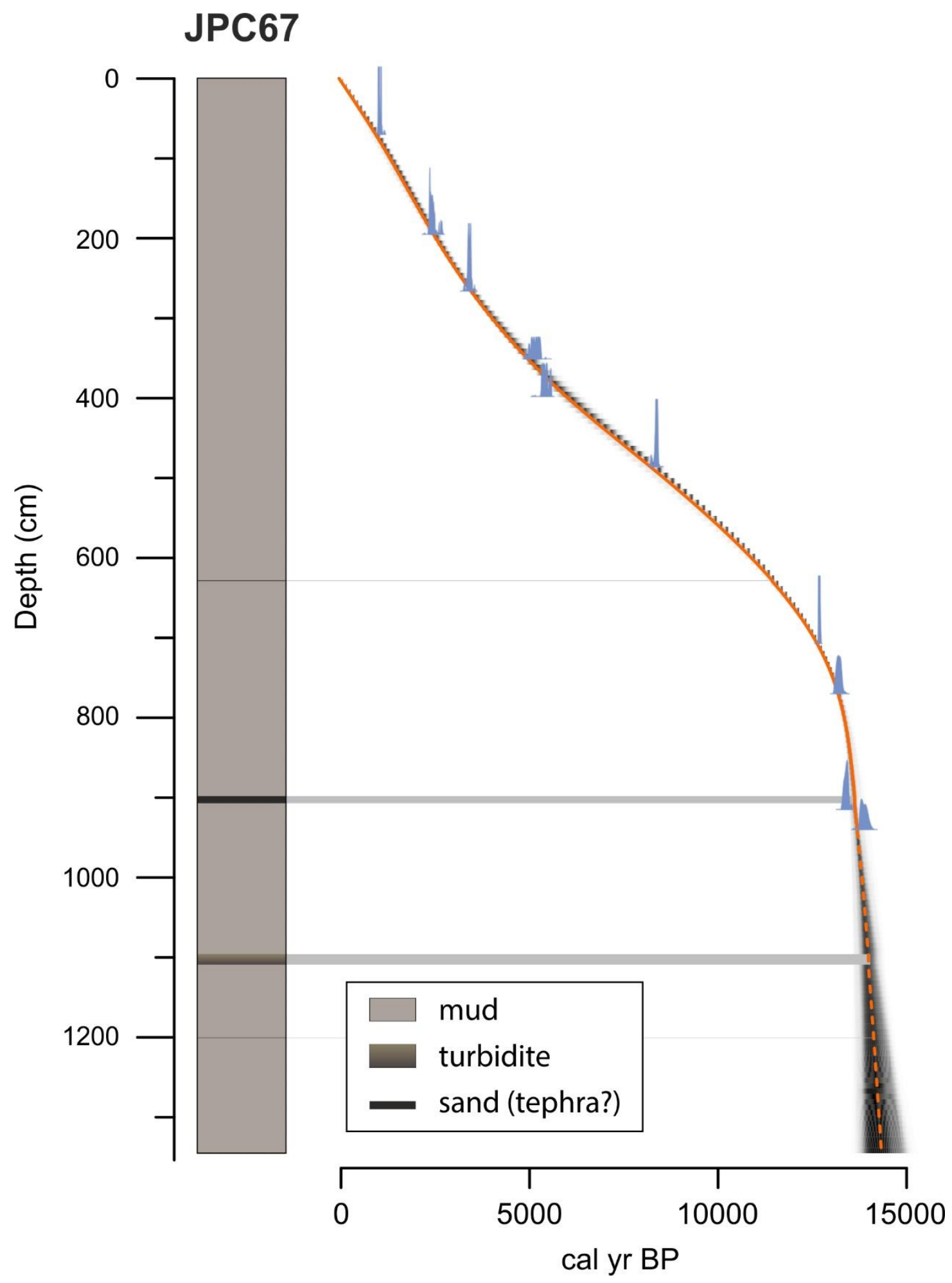

Bertrand et al - Figure 2 


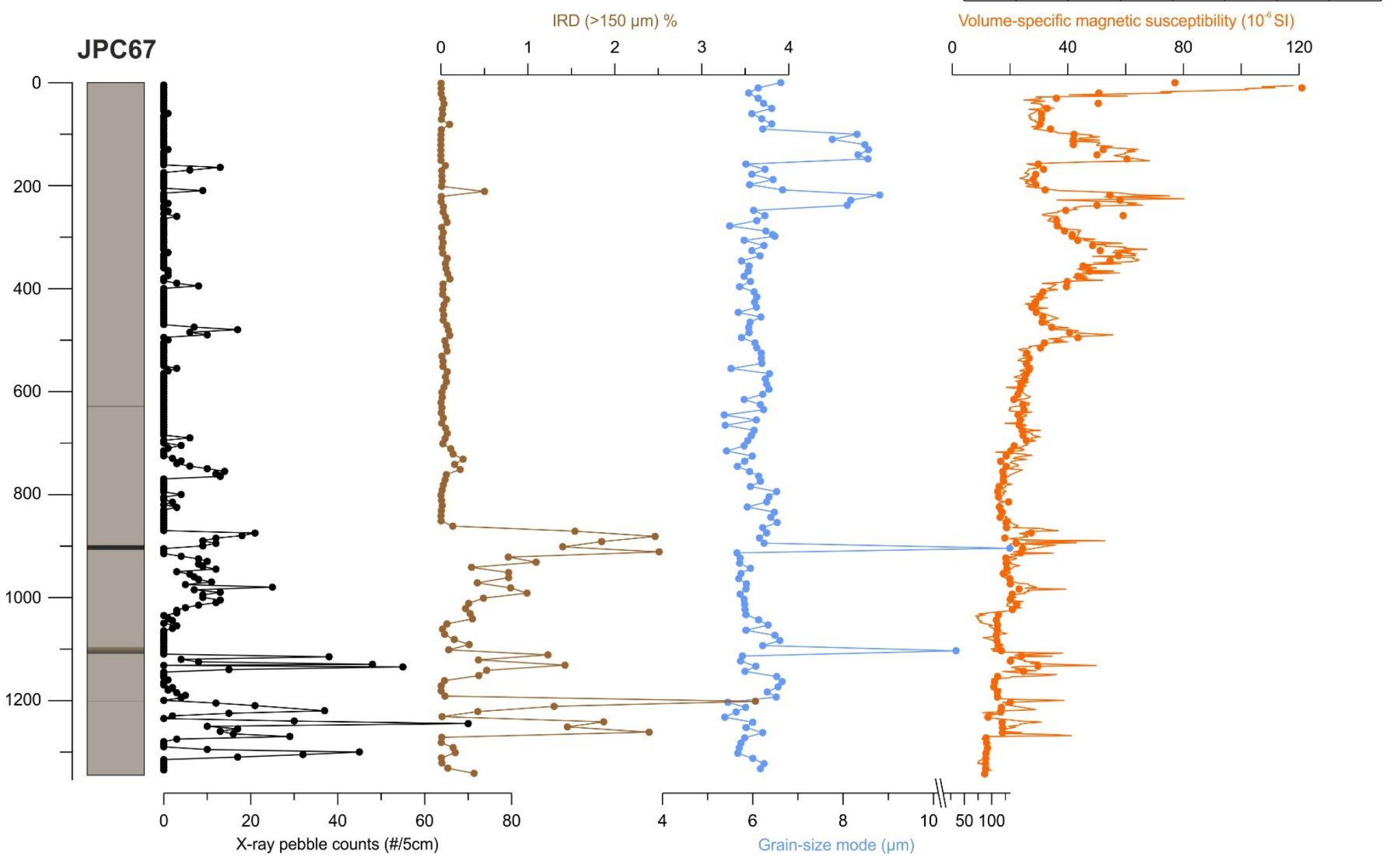

Bertrand et al - Figure 3 


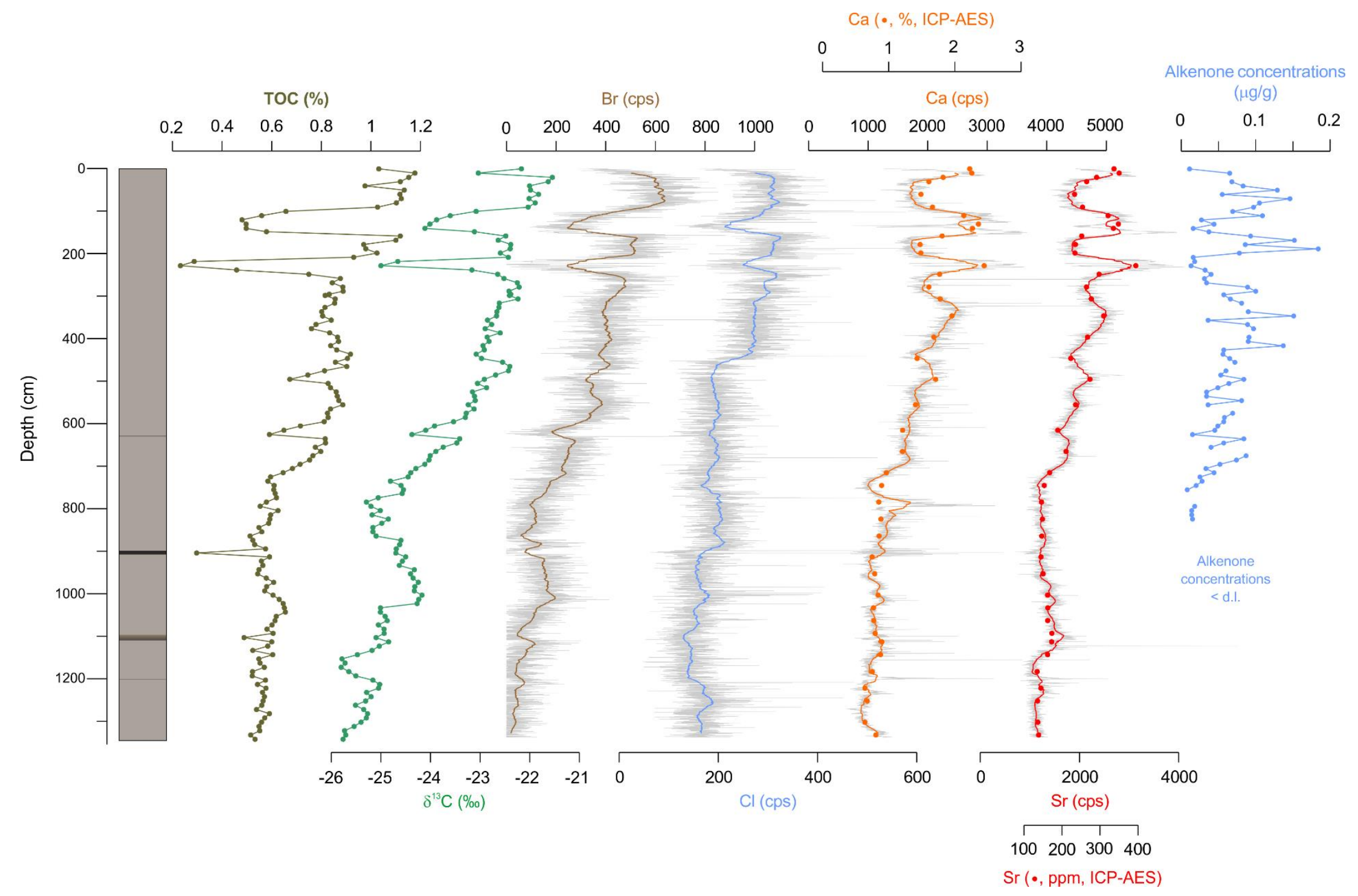

Bertrand et al. - Figure 4 


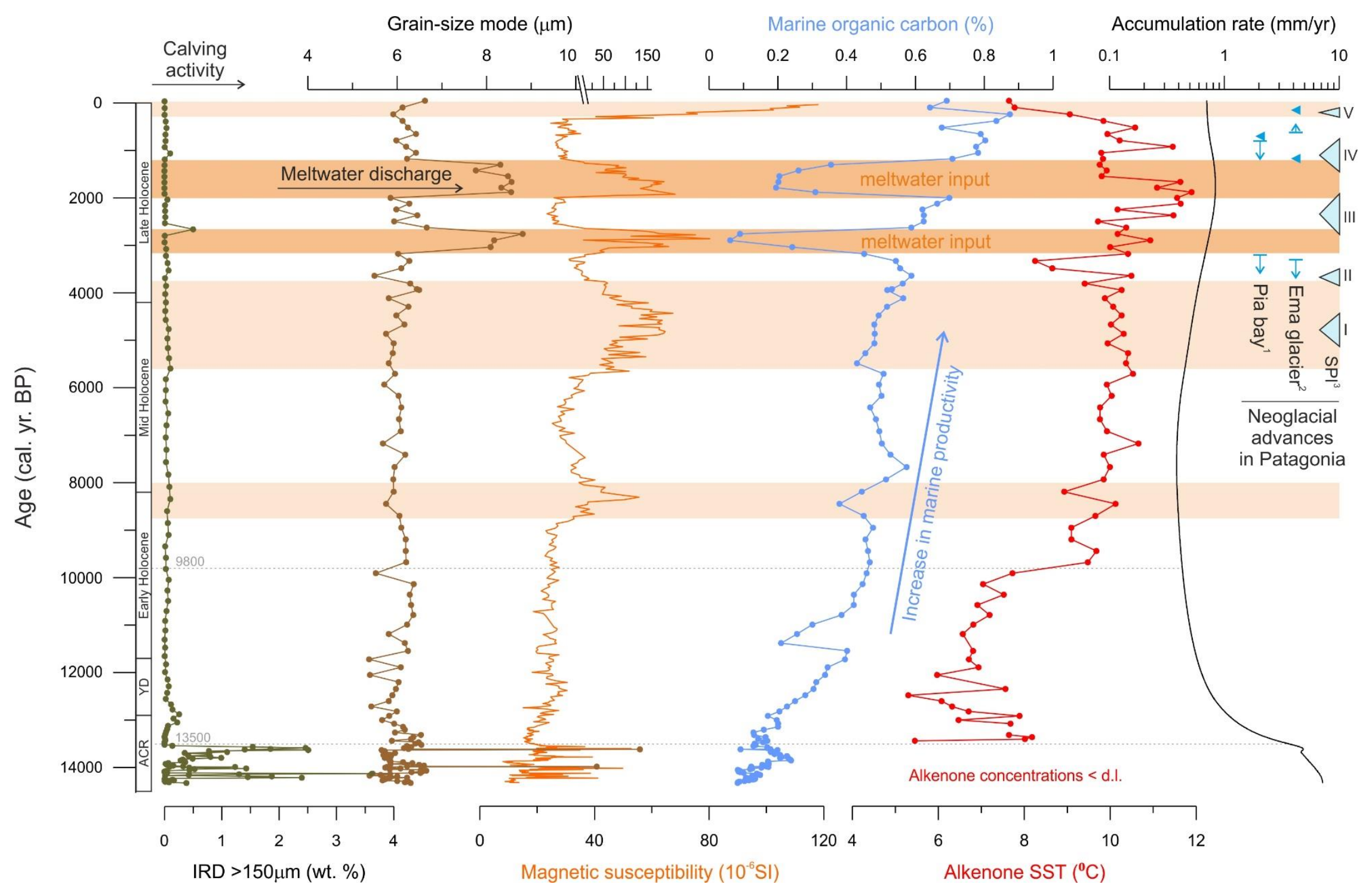

Bertrand et al - Figure 5 


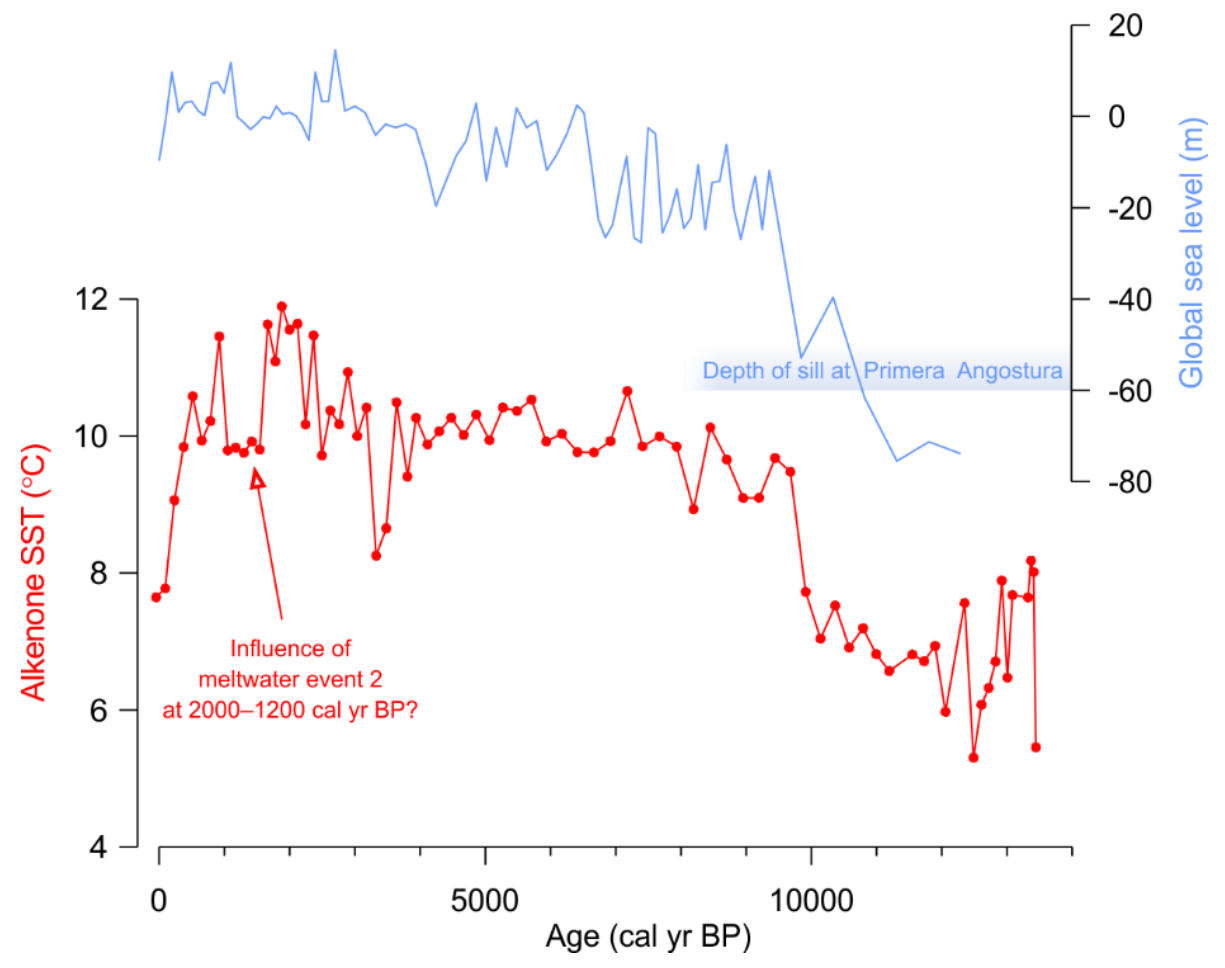

Bertrand et al - Figure 6 


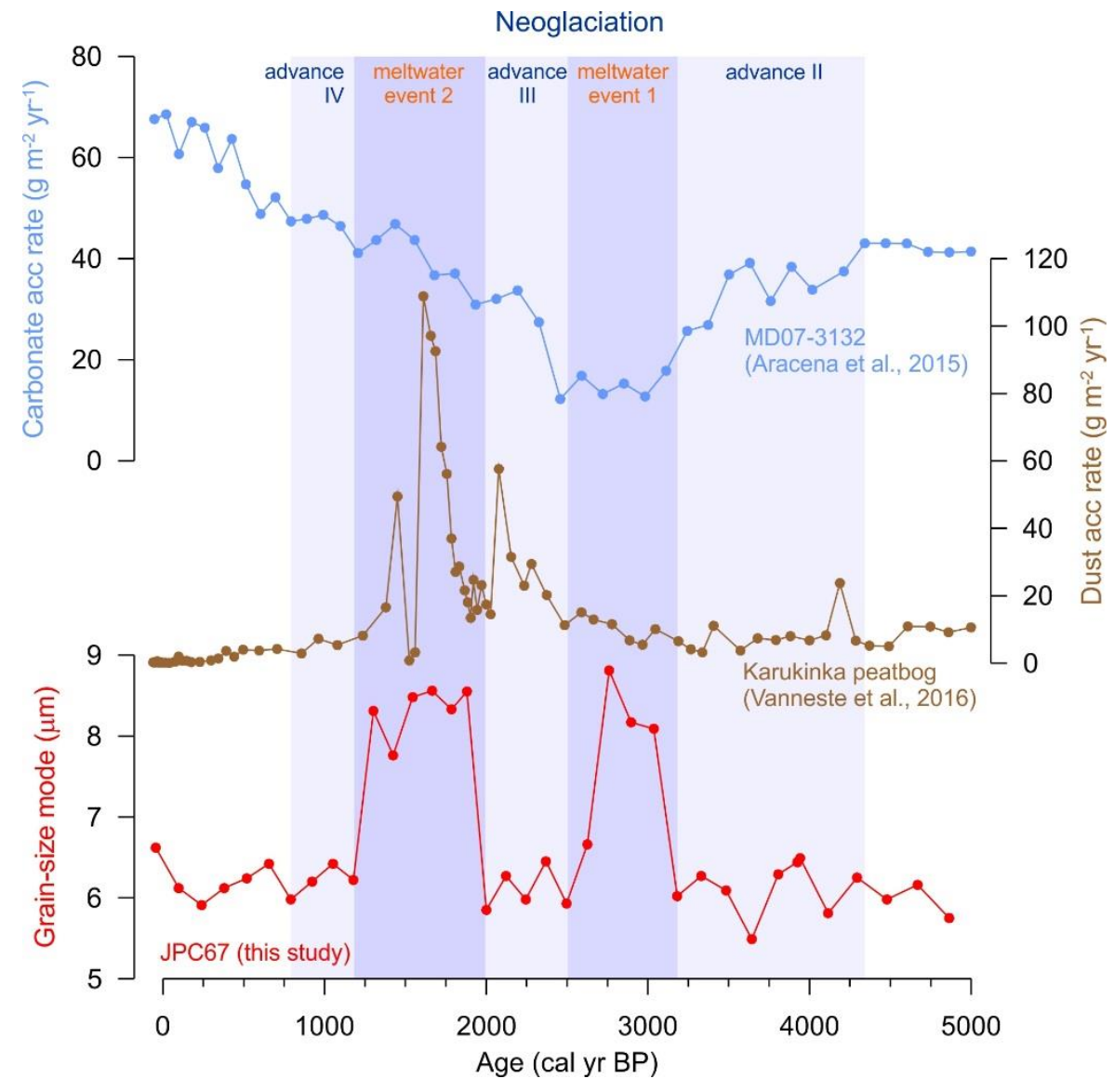

Bertrand et al - Figure 7 


\section{Appendix - Supplementary material}

\section{Appendix 1}

In addition to sediment core JPC67, we also analyzed the geochemical composition of a river sediment sample collected in the outwash plain of the western branch of Marinelli glacier in 2009 (RS09-36; Fig. 1). The sample was freeze-dried, separated into seven grain-size fractions finer than $90 \mu \mathrm{m}$, and the organic and inorganic geochemical composition of the sub-samples as well as their mass-specific magnetic susceptibility were measured as described in the main text. Their mineralogical composition was also analyzed by $\mathrm{X}$-ray diffraction.

Results show that magnetic

River sediment sample RS09-36 susceptibility (MS) and the concentrations of $\mathrm{Ca}$ and $\mathrm{Sr}$ are strongly related to grain-size. Since pyroxene is concentrated in the same grain-size fractions, variations in $\mathrm{Ca}$, $\mathrm{Sr}$ and $\mathrm{MS}$ most likely reflect mineralogical sorting.

Likewise, total organic carbon (TOC) is clearly higher in the finegrained fraction of the sediment, while $\delta^{13} \mathrm{C}$ is not significantly affected by grain-size. This confirms the use of the $\delta^{13} \mathrm{C}$ value of $-26.85 \%$ o to characterize the terrestrial end-member of the sedimentary organic matter.

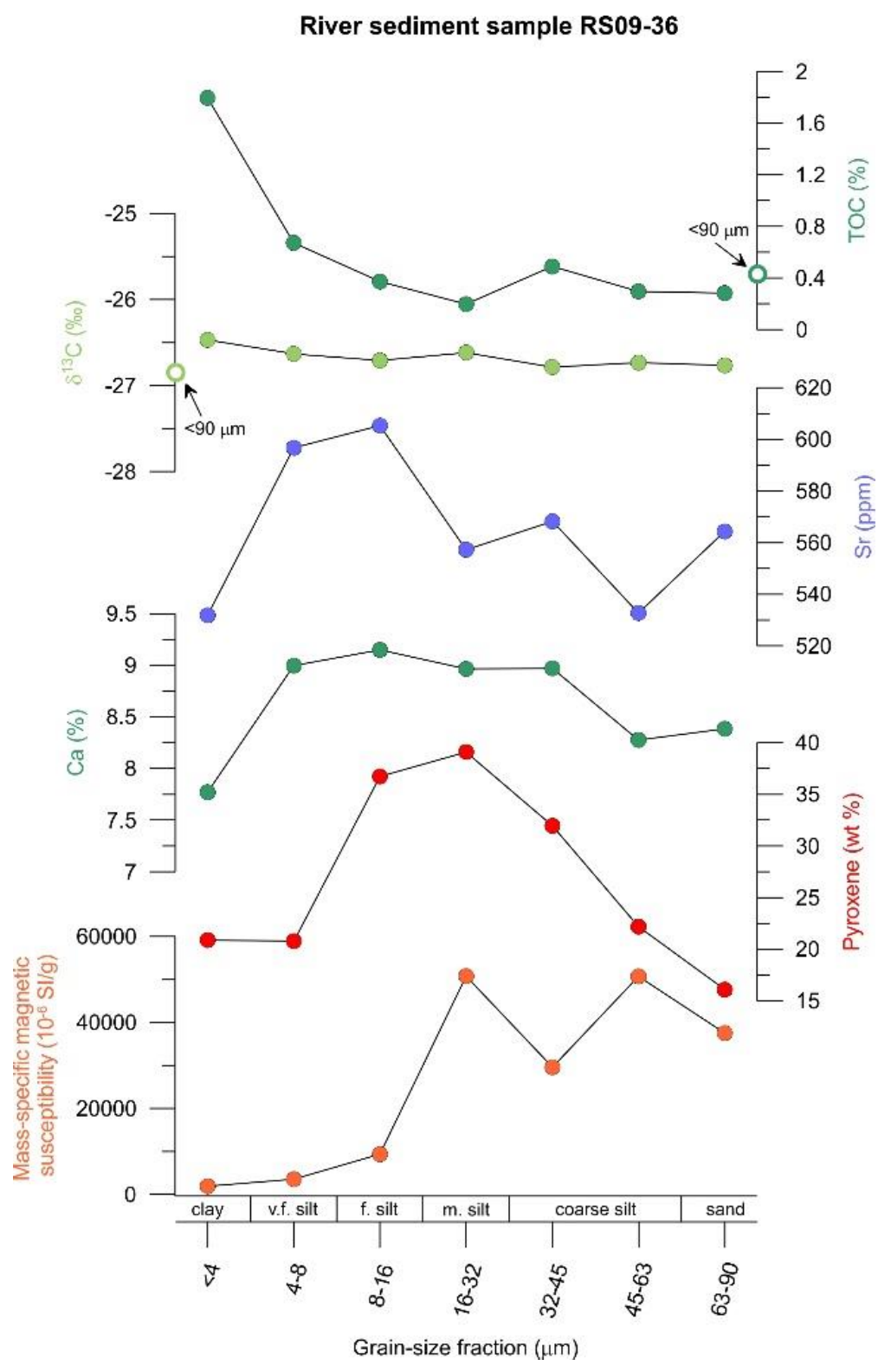




\section{Appendix 2}

Total organic carbon (TOC) concentrations of sediment core JPC67, sub-divided into terrestrial (terr) and marine organic carbon based on the $\delta^{13} \mathrm{C}$ data. The end-member values were $-19.86 \%$ ofor the marine end-member (Bertrand et al., 2012b) and $-\mathbf{2 6 . 8 5} \%$ ofor the terrestrial end-member (Appendix 1).

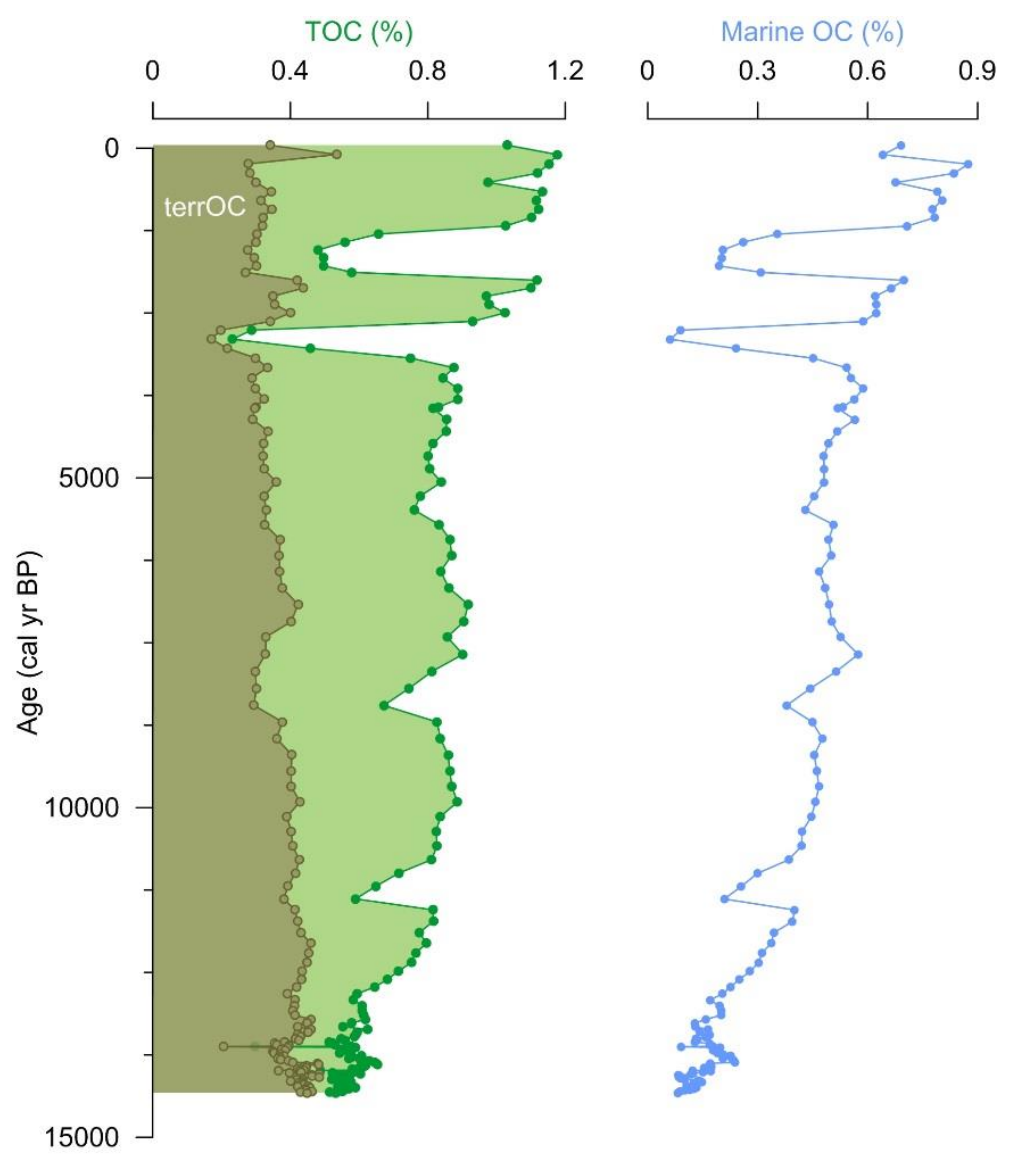




\section{Appendix 3}

Alkenone concentrations and calculated $\mathrm{U}^{\mathrm{K}^{\prime}}{ }_{37} \mathrm{SST}$ compared to marine organic carbon concentrations.

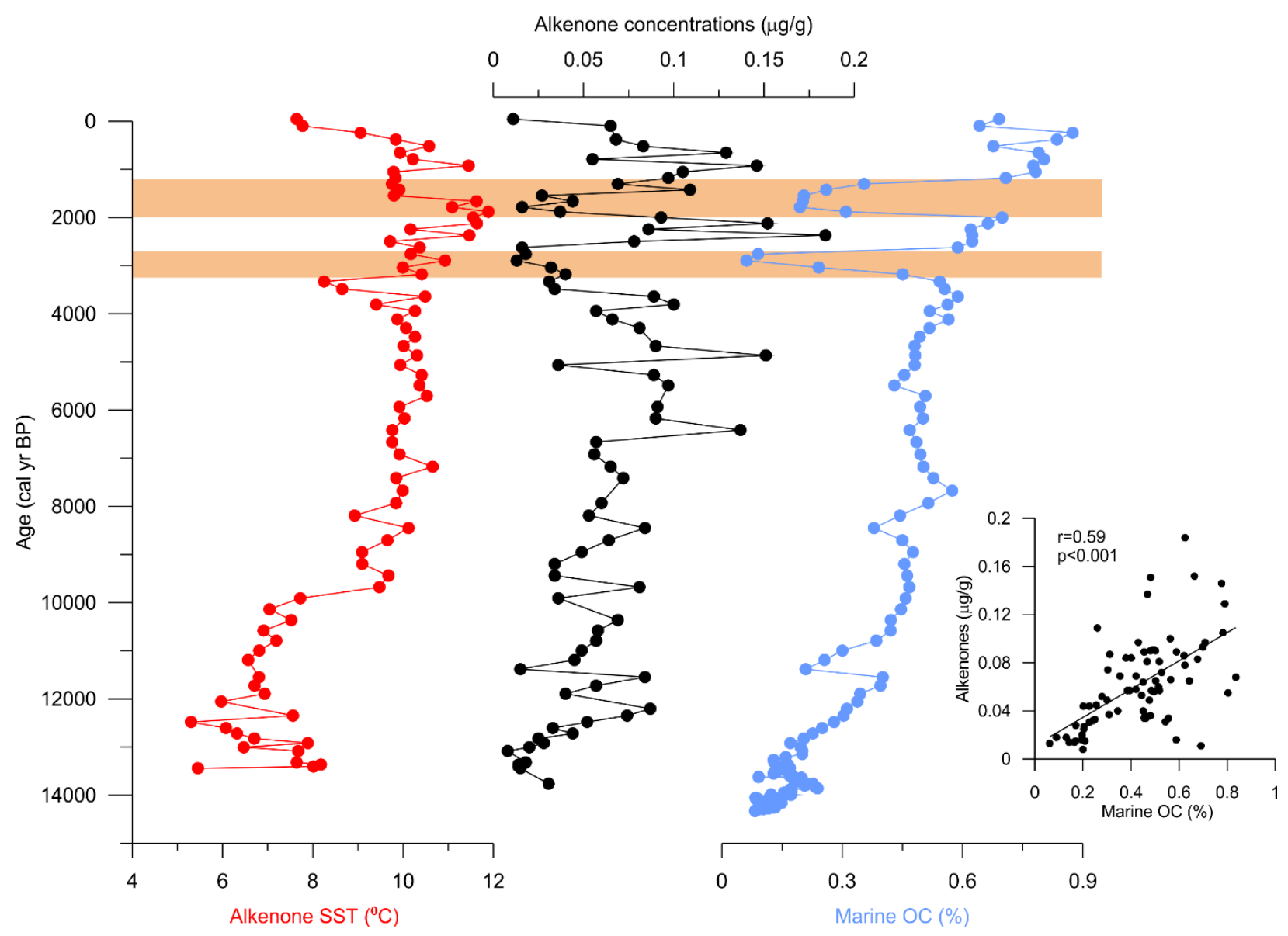

